\title{
Association of postpartum hypocalcemia with early-lactation milk yield, reproductive performance, and culling in dairy cows
}

\author{
P. L. Venjakob, ${ }^{\star} \dagger$ L. Pieper, $\ddagger$ W. Heuwieser, ${ }^{* 1}$ and S. Borchardt ${ }^{*}$ \\ ${ }^{*}$ Clinic for Animal Reproduction, Faculty of Veterinary Medicine, Freie Universität Berlin, 14163 Berlin, Germany \\ †Veterinary practice G. Thiele, 15837 Baruth/Mark, Germany \\ łInstitute for Veterinary Epidemiology and Biostatistics, Faculty of Veterinary Medicine, Freie Universität Berlin, 14163 Berlin, Germany
}

\begin{abstract}
Periparturient hypocalcemia is frequently observed and considered as a gateway disease that is associated with various health issues. The objective of this study was to evaluate the association of hypocalcemia with early-lactation milk yield, reproductive performance, and culling across a large number of different managerial systems. A prospective cohort study was conducted based on a convenience sample of 125 dairy herds from 8 federal states of Germany between February 2015 and August 2016. A blood sample was drawn from 1,709 animals within $48 \mathrm{~h}$ after parturition and analyzed for serum calcium concentration. After discarding cows (n $=283$ ) with missing data, a total of 1,426 cows were considered for final analyses. The median time from calving to sampling was $14.0 \mathrm{~h}$ (interquartile range $=$ 5.0-24.9 h). For each herd, a record of the herd management software was requested $150 \mathrm{~d}$ after the last cow was sampled. Serum calcium concentration of each cow was associated with early-lactation milk yield (Dairy Herd Improvement Association equivalent test 1 to 3), reproductive performance [days in milk (DIM) at first artificial insemination (AI), pregnancy at first AI, time to pregnancy within 150 DIM], and culling (until 60 DIM) data. Generalized linear mixed models were used to analyze continuous or categorical data. Shared frailty models were used for time to event data. Five different thresholds were used to define hypocalcemia. Thresholds ranged from 1.8 to $2.2 \mathrm{mmol} / \mathrm{L}$ using $0.1-\mathrm{mmol} / \mathrm{L}$ increments. Clinical hypocalcemia was defined as serum calcium concentration $<2.0 \mathrm{mmol} / \mathrm{L}$ in combination with clinical signs (e.g., recumbency). The effect of hypocalcemia on milk yield was conditional on parity. In primiparous cows a serum calcium concentration $<2.0 \mathrm{mmol} / \mathrm{L}$ ( $6.4 \%$ of cows were below this threshold) had no effect on milk production, whereas there was a tendency for multiparous cows with a serum calcium
\end{abstract}

Received November 27, 2017

Accepted May 22, 2018.

${ }^{1}$ Corresponding author: w.heuwieser@fu-berlin.de concentration $<2.1 \mathrm{mmol} / \mathrm{L}$ ( $63.2 \%$ of cows were below this threshold) to produce $0.80 \mathrm{~kg} / \mathrm{d}$ more milk compared with multiparous cows at or above the threshold. Multiparous cows suffering from clinical hypocalcemia produced $2.19 \mathrm{~kg} / \mathrm{d}$ less milk compared with normocalcemic cows in early lactation. Calcium status was not associated with days to first insemination. Cows with a serum calcium concentration $<1.9 \mathrm{mmol} / \mathrm{L}$ (34.6\% of cows below this threshold) had decreased odds (odds ratio $=0.56)$ of pregnancy at first AI. A serum calcium concentration $<1.8 \mathrm{mmol} / \mathrm{L}$ ( $24.1 \%$ of cows below this threshold) had a significant effect on time to pregnancy. Compared with animals with a serum calcium concentration $\geq 1.8 \mathrm{mmol} / \mathrm{L}$, the hazard of becoming pregnant within 150 DIM was reduced when cows had a serum calcium concentration $<1.8 \mathrm{mmol} / \mathrm{L}$ (hazard ratio $=$ 0.68). Cows with a serum calcium concentration $<2.0$ $\mathrm{mmol} / \mathrm{L}$ (44.3\% of cows were below this threshold) had a 1.69 times greater hazard of being culled within the first 60 DIM compared with normocalcemic animals. The present study shows that the association of hypocalcemia with milk yield was conditional on parity and serum calcium concentration measured once within 48 $\mathrm{h}$ after calving. Considering reproductive performance and culling in early lactation, a negative effect of postpartum hypocalcemia was demonstrated.

Key words: hypocalcemia, milk fever, reproduction, dairy cow

\section{INTRODUCTION}

Transition cows face the challenge of an increased requirement for minerals, especially calcium, to support lactogenesis in early lactation (Goff, 2014). To compensate for this challenge, homeorhetic mechanisms take place to adapt to such increased demands (MartínTereso and Martens, 2014). Unsuccessful adaptation leads to hypocalcemia around parturition and has been associated with increased occurrence of diseases (Martinez et al., 2012), decreased milk production (Chapinal et al., 2012b), increased culling risk (Seifi et al., 2011; Roberts et al., 2012), and impaired reproductive per- 
formance (Martinez et al., 2012; Ribeiro et al., 2013; Caixeta et al., 2017). Megahed et al. (2018) demonstrated that serum calcium concentration decreased 9 $\mathrm{h}$ before calving and increased back to the reference range approximately $72 \mathrm{~h}$ after calving. Although negative associations of hypocalcemia with production and health were not investigated in this study, it suggests that the major risk period for hypocalcemia might be within this time frame. Hypocalcemia can be either clinical (i.e., recumbency) or subclinical. With a better understanding of the hormonal regulation of calcium mobilization in the periparturient cow (Goff, 2008) and appropriate nutritional management (e.g., DCAD) during the dry period and early lactation, incidence rates of clinical hypocalcemia can be as low as 1\% (Oetzel and Miller, 2012). In a recent multisite study comprising 115 herds in Germany, however, the incidence of clinical hypocalcemia averaged $7.2 \%$ (Venjakob et al., 2017).

Subclinical hypocalcemia has been defined using thresholds ranging from 2.0 to $2.3 \mathrm{mmol} / \mathrm{L}$ (Seifi et al., 2011; Chapinal et al., 2012b; Roberts et al., 2012; Wilhelm et al., 2017). Commonly, the threshold used to categorize a cow as hypocalcemic has been $\leq 2.0$ $\mathrm{mmol} / \mathrm{L}$ and has often been applied in studies (DeGaris and Lean, 2008; Reinhardt et al., 2011; Wilhelm et al., 2017). The origin of this threshold, however, was arbitrary, and recent studies have reported higher thresholds. It was shown that hypocalcemia using the thresholds $\leq 2.1, \leq 2.2$, or $\leq 2.3 \mathrm{mmol} / \mathrm{L}$ was associated with a negative health outcome such as displaced abomasum and metritis (Chapinal et al., 2011, 2012b; Martinez et al., 2012) or an increased culling risk (Seifi et al., 2011; Roberts et al., 2012). These studies, however, considered a longer risk period postpartum (i.e., 3-7 DIM).

The association of hypocalcemia with milk production is inconsistent in the literature. Evidence exists that hypocalcemia around parturition is associated with decreased milk yield (Chapinal et al., 2012b). Another study does not show an effect of hypocalcemia on milk production (Martinez et al., 2012). In contrast, some studies even suggest that cows suffering from subclinical hypocalcemia produce more milk during early lactation (Jawor et al., 2012; Gild et al., 2015) compared with normocalcemic cows.

It has been shown consistently that the risk of culling during the first $60 \mathrm{~d}$ of lactation was greater when serum calcium concentration was $\leq 2.2 \mathrm{mmol} / \mathrm{L}$ in the first week postpartum [odds ratio $(\mathbf{O R})=1.5$; Roberts et al., 2012]. Other authors found a 2.4 and 5.3 times greater risk for culling when serum calcium concentration was $\leq 2.2$ and $\leq 2.3 \mathrm{mmol} / \mathrm{L}$ in the first and second week postpartum, respectively (Seifi et al., 2011).
Some epidemiological multisite studies indicate a negative association of hypocalcemia in the first week postpartum with health, production, and reproductive performance. Although these epidemiological studies showed an association and some evidence for a causal relationship between hypocalcemia and an increased risk for infectious diseases (Martinez et al., 2014), longer risk periods have to be evaluated with caution. It is also possible that reduced feed intake affects serum calcium levels before clinical signs of disease become apparent, as most recently shown by Pinedo et al. (2017) for cows suffering from puerperal metritis. Considering a relatively long risk period of 1 wk might lead to an underestimation of the prevalence and an overestimation of the effect size caused by hypocalcemia. Therefore, the objective of this prospective cohort study was to evaluate the association of hypocalcemia within $48 \mathrm{~h}$ after parturition with early-lactation milk yield, culling, and reproductive performance in German dairy herds.

\section{MATERIALS AND METHODS}

\section{Study Population}

A prospective cohort study was conducted based on a convenience sample of 125 dairy herds from 8 federal states of Germany between February 2015 and August 2016. Details and the sample size calculation have been described previously (Venjakob et al., 2017). In brief, inclusion criteria for herds were (1) participation in a federal DHIA equivalent testing system, (2) freestall housing with at least 100 milking cows, (3) feeding of a TMR-based diet, and (4) use of computerized herd management software. Average herd size was 513 and ranged from 112 to 2,607 lactating cows. The average milk production (305-d ECM, $4.0 \%$ fat, $3.4 \%$ protein) was $9,231 \mathrm{~kg}$ (range: 6,257-10,880 kg). Holstein Friesian cows were the predominant breed on 122 farms. Two farms kept Simmental cattle, and 1 farm kept Jersey cattle as the main breed.

\section{Experimental Procedures}

Veterinary practitioners were invited to participate in the study by an information leaflet sent out by regular mail. Participating practices were informed about the nature and duration of the study and received a package containing blood serum collection systems (SMonovette 9-mL Z, Sarstedt AG \& Co, Nürnbrecht, Germany), cryo-vials (Cryoröhrchen, Carl Roth GmbH \& Co. KG, Karlsruhe, Germany) to store serum at $-20^{\circ} \mathrm{C}$ until analysis, and a written standard operating procedure that described which information to record for each cow enrolled and how to examine the cow be- 
fore blood collection. A case report form for each cow was provided to document time of sampling, ear tag number, time of calving, calving ease (i.e., unassisted calving or assisted calving with at least 1 person), clinical symptoms of hypocalcemia (i.e., recumbency), and parity. Administration of calcium products, time relative to calving, and route of administration (i.e., subcutaneous, intravenous, oral) of these products were also documented. Cows with missing information were excluded from analyses $(\mathrm{n}=175)$.

Animals were enrolled by convenience when a veterinarian visited the farm on a given day and an animal met the inclusion criteria of being within $48 \mathrm{~h}$ after parturition. For each herd, a backup of the management software was requested $150 \mathrm{~d}$ after the last cow was sampled. Herds that did not provide a record were excluded from analyses $(\mathrm{n}=9)$.

\section{Blood Sampling and Laboratory Analyses}

Blood samples were taken from the coccygeal vessels using a vacuum blood serum collection system. According to the standard operating procedure, samples were kept at room temperature and allowed to clot. Within $5 \mathrm{~h}$ of blood collection, samples were centrifuged to harvest serum, which was frozen at $-20^{\circ} \mathrm{C}$. Analysis of blood samples was carried out by a commercial laboratory (Synlab Services GmbH, Augsburg, Germany; accreditation number D-PL-14016-01-00 according to the European regulation no. 765/2008). Total serum calcium concentration was analyzed using spectrophotometry (AU680, Beckman Coulter, Krefeld, Germany). The inter- and intra-assay coefficients of variation were $1.03 \%(\mathrm{Ca}, 2.37 \mathrm{mmol} / \mathrm{L} ; \mathrm{n}=16)$ and $1.19 \%(\mathrm{Ca}, 2.40$ $\mathrm{mmol} / \mathrm{L} ; \mathrm{n}=10)$, respectively.

\section{Early-Lactation Milk Yield}

All herds participated in a federal DHIA equivalent testing system. Data collection included date of the test day, DIM at the test day, milk yield $(\mathrm{kg} / \mathrm{d})$, milk fat percentage, milk protein percentage, and SCC. For analysis of the early-lactation milk yield, the results of the first 3 DHIA tests were evaluated. To evaluate the association of SCC with milk yield, the linear score was used. Therefore, the SCC was log-transformed as $[\ln (\mathrm{SCC} / 100) / \ln (2)]+3$ (Ali and Shook, 1980).

\section{Reproductive Management}

Most herds used a combination of estrus detection and timed AI or an intervention based on ovarian diagnostics to facilitate first postpartum AI. None of the herds exclusively used timed AI. Inseminations and pregnancy diagnosis were recorded until 150 DIM. Pregnancy diagnosis was performed by transrectal palpation or ultrasonography between 32 and $45 \mathrm{~d}$ after parturition. Reproductive performance was evaluated by DIM at first service, first service conception risk (FSCR), and time to pregnancy within 150 DIM.

\section{Postpartum Culling}

Culling events were collected from enrollment in the study until 60 DIM. Cows were considered to be culled during the postpartum period if they were removed from the herd at $\leq 60$ DIM, except for sales for dairy purposes.

\section{Statistical Analyses}

Individual cow data were transferred to Microsoft Excel (Office 2013; Microsoft Deutschland Ltd., Munich, Germany). Statistical analyses were performed using SPSS for Windows (version 22.0; SPSS Inc., Chicago, IL).

Appropriate thresholds for defining hypocalcemia based on serum calcium levels associated with an increased risk of negative downstream events were first determined by creating incremental thresholds of 0.1 $\mathrm{mmol} / \mathrm{L}$ of calcium from 1.8 to $2.2 \mathrm{mmol} / \mathrm{L}$. Showing an association with negative health or production outcomes in recent literature (Seifi et al., 2011; Chapinal et al., 2012b; Jawor et al., 2012; Martinez et al., 2012), this range of thresholds appeared plausible. These thresholds were evaluated using dichotomous variables, designating a 1 value for all samples below each threshold and assigning a value of 0 to all values at or above each threshold. Based on the nature of the outcome variable (e.g., continuous, categorical, and time to event) for these negative downstream events, we used 3 different approaches. In all cases, thresholds of calcium were identified from serum obtained from 0 to $48 \mathrm{~h}$ postpartum.

To identify a threshold associated with a change in milk production, we used the following approach. A data set was created from information of the first 3 DHIA tests and serum calcium levels. Hierarchical dummy variables were created in the same manner as described above and ranged from 1.8 to $2.2 \mathrm{mmol} / \mathrm{L}$ of serum calcium concentration. To evaluate the effect of calcium status (i.e., normocalcemia vs. hypocalcemia) on milk yield across the first 3 DHIA tests, repeated measures ANOVA with first-order autoregressive covariance was performed using the GENLINMIXED procedure of SPSS. The outcome variable was milk yield $(\mathrm{kg} / \mathrm{d})$. Cow was the experimental unit, and herd was considered as a random effect. The model 
accounted for the cluster effect of cows within herd. Each dummy variable for serum calcium was offered to the model separately. The calcium threshold for the dummy variable with the most extreme (negative or positive) $\beta$ coefficient and the smallest $P$-value was chosen as the threshold for defining hypocalcemia. Optimum thresholds based on a combination of lowest $P$-value and greatest magnitude of the effect were 2.0 and $2.1 \mathrm{mmol} / \mathrm{L}$ for primiparous and multiparous cows, respectively. According to the model-building strategies described by Dohoo et al. (2009), each parameter considered for the mixed model was separately analyzed in a univariable model. Only parameters resulting in univariable models with $P \leq 0.2$ were included in the final mixed model. Selection of the model that best fit the data was performed by using a backward-stepwise elimination procedure that removed all variables with $P>0.10$ from the model. Regardless of the significance level, calcium status was forced to remain in the model. We used separate models for primiparous and multiparous animals to account for their marked difference in milk yield and to include previous-lactation milk as a covariate for multiparous cows. The initial model for primiparous cows contained the following explanatory variables as fixed effects: breed (Holstein, Jersey, Simmental), linear score (continuous), oral calcium supplementation (yes vs. no), time of DHIA equivalent test (first, second, or third test after parturition), calving ease (unassisted calving vs. assisted calving), stillbirth (yes vs. no), twins (yes vs. no), time from calving to sampling (continuous), and calcium status 0 to $48 \mathrm{~h}$ after parturition (normocalcemia vs. hypocalcemia). To account for the possible effect of sampling time on serum calcium concentration, the interaction of these parameters was offered in the model. The initial model for multiparous cows contained the same explanatory variables as for primiparous cows. Additionally, the 305-d milk yield of the previous lactation (continuous), clinical hypocalcemia (yes vs. no), and parity (lactation 2,3 , or $4+$ ) were considered for multiparous cows.

Using failure of conception at first AI as the biological outcome of interest, sensitivity and specificity for each threshold were calculated. The serum calcium threshold with the greatest sum of sensitivity and specificity was selected for further logistic regression analysis. To further evaluate the effect of calcium status on FSCR, a logistic regression model using the GENLINMIXED procedure of SPSS was built. Cow was the experimental unit. Herd was considered as a random effect. The model accounted for the cluster effect of cows within herd. Model building was conducted as recommended by Dohoo et al. (2009), where each parameter was first analyzed separately in a univariable model. Only parameters resulting in univariable models with $P \leq$
0.2 were included in the final mixed model. Selection of the model that best fit the data was performed by using a backward-stepwise elimination procedure that removed all variables with $P>0.10$ from the model. The initial model contained the following explanatory variables as fixed effects: parity (lactation 1, 2, 3, or $4+$ ), breed (Holstein, Jersey, Simmental), calving ease (unassisted calving vs. assisted calving), DIM at first AI (continuous), oral calcium supplementation (yes vs. no), stillbirth (yes vs. no), twins (yes vs. no), time from calving to sampling (continuous), calcium status (normocalcemia, hypocalcemia), and the interaction of sampling time and hypocalcemia. Regardless of the significance level, type of calcium status was forced to remain in the model.

Cox proportional hazards were used to model the time to event outcomes while accounting for herd as a random effect and cluster-specific correlations (shared frailty term; cows within farm). Cows were censored if they were culled before first insemination or pregnancy or at the end of the observation period. The models were constructed for each of the 5 cutoffs $(1.8,1.9,2.0$, 2.1 , and $2.2 \mathrm{mmol} / \mathrm{L}$ ) for serum calcium concentration. The variables oral calcium supplementation, breed, parity, clinical hypocalcemia, assisted calving, time from calving to sampling, twin birth, and stillbirth or a combination thereof were tested as risk factors. Models with the most extreme $\beta$-value for hypocalcemia and the lowest $P$-value were selected. Proportional hazards assumption was graphically assessed by plotting the $-\ln (-\ln ($ survival $))$ curves for subclinical hypocalcemia and normocalcemia against the $\ln$ (survival time). Proportional hazards assumption was assumed to be met when the lines were approximately parallel. Frailty models were built using the computer program Stata (Stata/IC 13.1 for Windows; StataCorp LP, Station, TX). Post hoc power analyses were performed using the $\mathrm{G}^{*}$ Power program (version 3.1.9.2; University of Düsseldorf, Düsseldorf, Germany).

\section{RESULTS}

Overall, blood samples were drawn from 1,709 animals at 0 to $48 \mathrm{~h}$ after calving from 125 farms. Nine farms with 108 animals were excluded from analyses because they did not provide a data backup. Another 175 animals were excluded because their case reports were incomplete or incorrect (Figure 1).

Data of 1,426 animals (83.4\%) from 107 farms were available for final analyses. Of those, 211 (14.8\%), 384 $(26.9 \%), 354(24.8 \%)$, and $477(33.5 \%)$ were in lactation $1,2,3$, and $\geq 4$, respectively. Median time from calving to sampling was $14.0 \mathrm{~h}$ (interquartile range $=$ 5.0-24.9). On average, 13 cows were sampled per herd. 
Further descriptive data of cows and herds enrolled are summarized in Table 1.

\section{Milk Yield}

Primiparous Cows. Serum calcium concentration $<2.0 \mathrm{mmol} / \mathrm{L}$ had no effect on milk yield of primiparous cows $(P=0.306)$. High SCC $(P=0.001)$ and stillbirth $(P=0.090)$ affected milk production negatively. Breed had a significant influence on milk yield $(P=0.006)$.

Multiparous Cows. Cows suffering from clinical hypocalcemia produced less milk than normocalcemic cows in early lactation $(-2.19 \mathrm{~kg} / \mathrm{d} ; P=0.003$; Table 2 ). There was a tendency for cows with a serum calcium concentration $<2.1 \mathrm{mmol} / \mathrm{L}$ to produce $0.80 \mathrm{~kg} / \mathrm{d}$ more milk than cows with a serum calcium concentration $\geq 2.1 \mathrm{mmol} / \mathrm{L}(P=0.058$; Table 2$)$.

\section{Reproductive Performance}

Time to First Insemination. Choosing the model with the most extreme $\beta$-value for hypocalcemia and the lowest $P$-value (threshold: $<2.2 \mathrm{mmol} / \mathrm{L}$ ), a significant effect $(P=0.296)$ on days to first insemination could not be detected. Median days to first insemination were 71 and 73 for normocalcemic and hypocalcemic animals, respectively.

First Service Conception Risk. Cows with a serum calcium concentration $<1.9 \mathrm{mmol} / \mathrm{L}$ had decreased
Table 1. Description of the cows and herds enrolled in this study

\begin{tabular}{lr}
\hline Variable & No. (\%) \\
\hline Cows culled until 60 DIM & $115(8.1)$ \\
Cows sold for dairy purposes & $18(1.3)$ \\
Breed of cows enrolled & \\
Holstein Friesian & $1,344(94.2)$ \\
Jersey & $56(3.9)$ \\
Simmental & $26(1.8)$ \\
Calving management & $208(14.6)$ \\
Assisted calving & $69(5.2)$ \\
Stillbirth & $23(1.7)$ \\
Twins & $269(18.9)$ \\
Preventive strategies against hypocalcemia & $23(1.6)$ \\
Cows receiving oral calcium supplementation & $10(9.4)$ \\
Cows receiving vitamin $D_{3}$ before calving & \\
Herds feeding anionic salts in the close-up diet & \\
\hline
\end{tabular}

odds $(\mathrm{OR}=0.56 ; P=0.001$; Table 3$)$ of pregnancy at first AI. There was no effect of clinical hypocalcemia on FSCR.

Time to Pregnancy. Calcium status had a significant influence on time to pregnancy (Figure 2). Cows with a serum calcium concentration $<1.8 \mathrm{mmol} / \mathrm{L}$ had a significantly reduced hazard of pregnancy compared with normocalcemic cows (hazard ratio $=0.68 ; P=$ 0.001). Median time to pregnancy was 109 and $134 \mathrm{~d}$ for animals with serum calcium concentrations $\geq 1.8$ and $<1.8 \mathrm{mmol} / \mathrm{L}$, respectively. Parity $(P=0.006)$ and stillbirth $(P=0.030)$ had a significant effect on time to pregnancy.

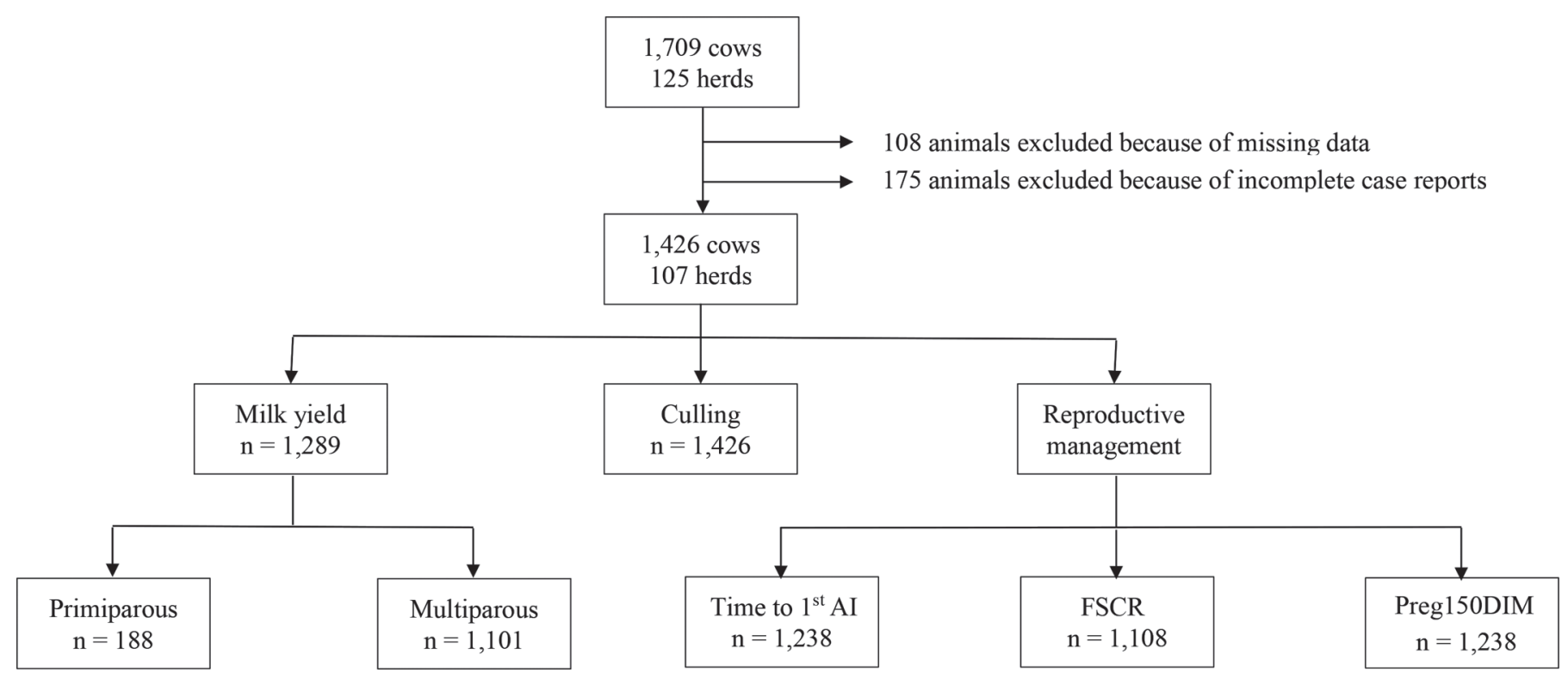

Figure 1. Flow chart of total number of animals screened for hypocalcemia and considered for final analyses. Number of observations included in each analysis might differ due to several reasons (e.g., culling, do-not-breed decision, missing information in the DHIA equivalent test). Time to 1 st $\mathrm{AI}=$ time to first insemination within $150 \mathrm{DIM}$. FSCR = first service conception rate. Preg150DIM = time to pregnancy within 150 DIM. 
Table 2. Association of serum calcium concentration $<2.1 \mathrm{mmol} / \mathrm{L}$, measured once within $48 \mathrm{~h}$ after parturition with milk production across the first 3 DHIA equivalent tests for 1,101 multiparous dairy cows

\begin{tabular}{|c|c|c|c|c|c|}
\hline \multirow[b]{2}{*}{ Variable $^{1}$} & \multirow{2}{*}{$\begin{array}{l}\text { Estimated } \\
\text { milk (kg) }\end{array}$} & \multirow[b]{2}{*}{$\mathrm{SE}$} & \multicolumn{2}{|c|}{$95 \%$ CI } & \multirow[b]{2}{*}{$P$-value } \\
\hline & & & Lower CI & Upper CI & \\
\hline Intercept & 26.02 & 0.88 & 24.30 & 27.73 & 0.001 \\
\hline \multicolumn{6}{|l|}{ Breed } \\
\hline Holstein & Referent & & & & \\
\hline Simmental & 0.87 & 2.40 & -3.83 & 5.57 & 0.717 \\
\hline Jersey & -6.07 & 2.70 & -11.36 & -0.77 & 0.025 \\
\hline Linear score & -0.73 & 0.07 & -0.86 & -0.60 & 0.001 \\
\hline \multicolumn{6}{|l|}{ DHIA test } \\
\hline First test & Referent & & & & \\
\hline Second test & 3.35 & 0.23 & 2.90 & 3.80 & 0.001 \\
\hline Third test & 1.43 & 0.29 & 0.86 & 1.99 & 0.001 \\
\hline \multicolumn{6}{|l|}{ Stillbirth } \\
\hline No & Referent & & & & \\
\hline Yes & -4.42 & 0.98 & -6.35 & -2.50 & 0.001 \\
\hline Previous lactation milk ${ }^{2}$ & 1.51 & 0.11 & 1.28 & 1.73 & 0.001 \\
\hline \multicolumn{6}{|l|}{ Parity } \\
\hline Lactation 2 & Referent & & & & \\
\hline Lactation 3 & -0.53 & 0.51 & -1.54 & 0.49 & 0.312 \\
\hline Lactation $4+$ & -0.99 & 0.52 & -1.99 & 0.01 & 0.053 \\
\hline \multicolumn{6}{|c|}{ Serum calcium concentration ${ }^{3}$} \\
\hline$\geq 2.1 \mathrm{mmol} / \mathrm{L}$ & Referent & & & & \\
\hline$<2.1 \mathrm{mmol} / \mathrm{L}$ & 0.80 & 0.42 & -0.03 & 1.63 & 0.058 \\
\hline \multicolumn{6}{|l|}{ Clinical hypocalcemia ${ }^{4}$} \\
\hline No & Referent & & & & \\
\hline Yes & -2.19 & 0.74 & -3.64 & -0.74 & 0.003 \\
\hline
\end{tabular}

${ }^{1}$ Model adjusted for the random effect of herd.

${ }^{2} 305$-d milk yield $(\mathrm{kg})$ of the previous lactation.

${ }^{3}$ Optimum threshold was chosen based on the combination of least $P$-value and the greatest magnitude of effect of hypocalcemia on milk yield for the first 3 DHIA equivalent tests. Serum calcium concentration was below the threshold in $63.2 \%(\mathrm{n}=696)$ of cows included in this model.

${ }^{4}$ Recumbent cows with a serum calcium concentration $<2.1 \mathrm{mmol} / \mathrm{L}$.

\section{Early-Lactation Culling}

Cows with a serum calcium concentration $<2.0$ $\mathrm{mmol} / \mathrm{L}$ had a 1.69 times greater hazard of being culled $(P=0.007$; Table 4$)$ in early lactation.

\section{DISCUSSION}

As recently reported, prevalence of clinical and subclinical hypocalcemia around parturition is high in German dairy herds, and most dairies did not implement

Table 3. Final multivariable logistic regression model evaluating the association of serum calcium $<1.9$ mmol/L measured once within $48 \mathrm{~h}$ after calving with the odds of pregnancy at first AI in 1,108 dairy cows

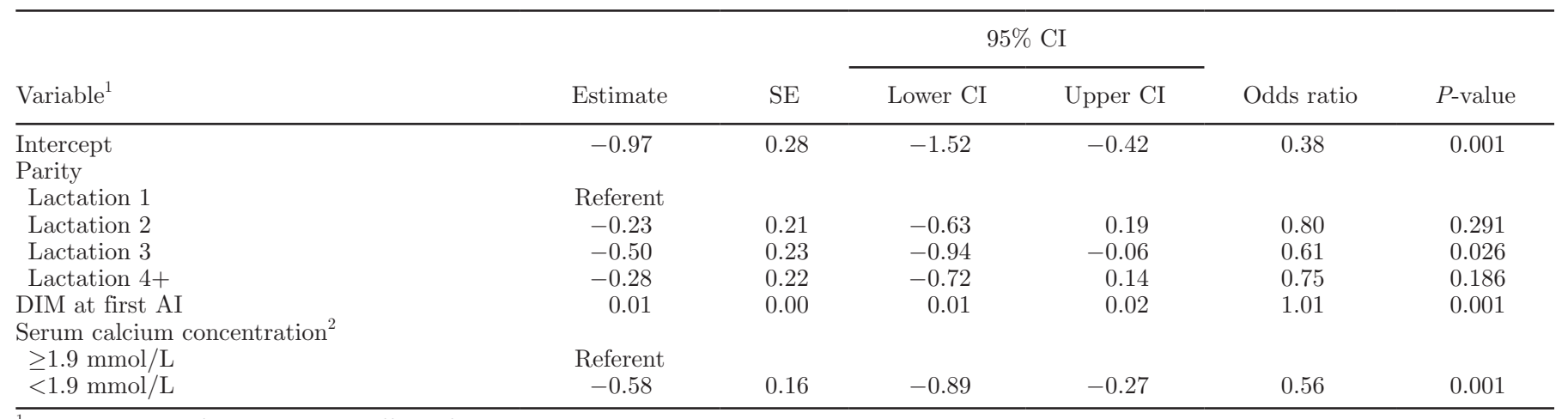

${ }^{1}$ Model adjusted for the random effect of herd.

${ }^{2}$ Serum calcium concentration was below the threshold in $34.6 \%(\mathrm{n}=383)$ of cows included in this model. 


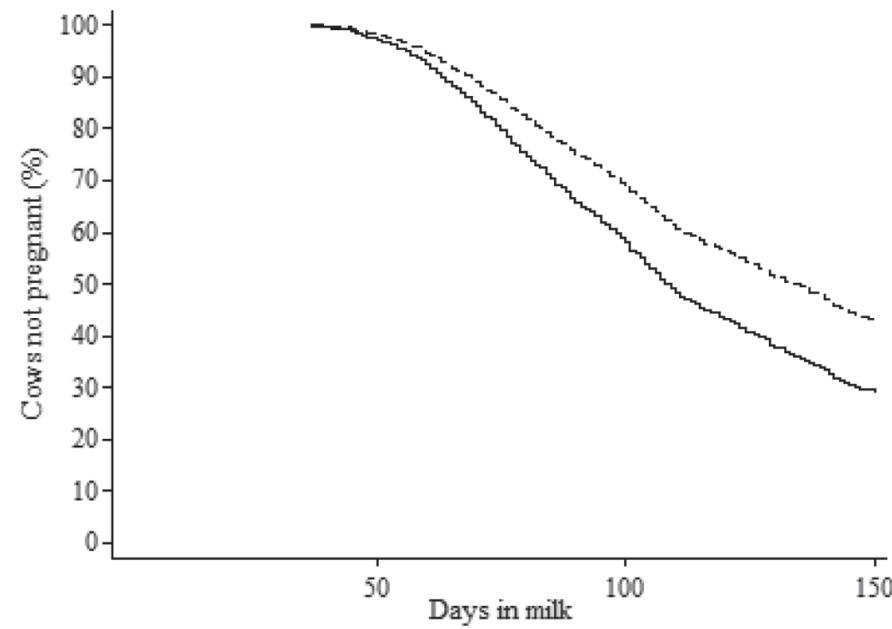

Figure 2. Kaplan-Meier survival analysis illustrating the association of a serum calcium concentration $\geq 1.8 \mathrm{mmol} / \mathrm{L}$ (solid line; $\mathrm{n}=$ 940 ) and a serum calcium concentration $<1.8 \mathrm{mmol} / \mathrm{L}$ (dashed line; $\mathrm{n}$ $=298$ ) with time to pregnancy within 150 DIM in 1,238 cows. Cows with a serum calcium concentration $<1.8 \mathrm{mmol} / \mathrm{L}$ had a significantly reduced hazard of pregnancy compared with normocalcemic cows (hazard ratio $=0.68 ; 95 \%$ CI: $0.56-0.83 ; P=0.001$ ). Median days to pregnancy were 134 and 109 for cows with a serum calcium concentration $<1.8 \mathrm{mmol} / \mathrm{L}$ versus cows with a serum calcium concentration $>1.8 \mathrm{mmol} / \mathrm{L}(P=0.001)$, respectively. Other variables included in the model were parity $(P=0.006)$ and stillbirth $(P=0.030)$.

a suitable preventive strategy (Venjakob et al., 2017). The results of the present study underline that hypocalcemia has negative consequences for reproductive performance and the risk of getting culled. The effect on milk yield was conditional on parity and severity of hypocalcemia. Different thresholds for serum calcium concentration 0 to $48 \mathrm{~h}$ after parturition were identified for these outcomes $(2.0$ and $2.1 \mathrm{mmol} / \mathrm{L}$ for milk yield of primiparous and multiparous cows, respectively; 1.9 $\mathrm{mmol} / \mathrm{L}$ for FSCR; $1.8 \mathrm{mmol} / \mathrm{L}$ for time to pregnancy; and $2.0 \mathrm{mmol} / \mathrm{L}$ for culling).
Serum calcium concentration $<2.0 \mathrm{mmol} / \mathrm{L}$ had no effect on milk yield of primiparous cows $(P=0.306)$. Multiparous cows with a serum calcium concentration $<2.1 \mathrm{mmol} / \mathrm{L}$ had a tendency toward higher milk yield $(+0.80 \mathrm{~kg} / \mathrm{d})$ in early lactation. This is in agreement with Neves et al. (2018), who investigated the association of hypocalcemia 0 to $12 \mathrm{~h}$ after parturition with early-lactation health, pregnancy at first AI, and milk production. Multiparous cows with a serum calcium concentration $\leq 1.95 \mathrm{mmol} / \mathrm{L}$ produced $1.1 \mathrm{~kg} / \mathrm{d}$ more milk across the first 9 DHIA tests compared with normocalcemic multiparous cows. In contrast, Chapinal et al. (2012a) found an association of hypocalcemia $(<2.1$ $\mathrm{mmol} / \mathrm{L}) 1 \mathrm{wk}$ prepartum and up to $3 \mathrm{wk}$ postpartum with decreased milk yield. Serum calcium concentration $\leq 2.1 \mathrm{mmol} / \mathrm{L} 1 \mathrm{wk}$ before and 2 and 3 wk after parturition was associated with $-3.2,-2.6$, and -3.5 $\mathrm{kg}$ of milk/d across the first 4 DHIA tests in lactation, respectively. Serum calcium concentration $\leq 2.1$ $\mathrm{mmol} / \mathrm{L}$ in wk 1,2 , and 3 postpartum were associated with $-2.6,-4.8$, and $-7.1 \mathrm{~kg}$ of milk/d only at first DHIA test, respectively, irrespective of parity. The authors speculated that the observed low calcium values might also be an indicator of inadequate feed intake rather than metabolic disease when considering such a long risk period. This assumption is in agreement with Pinedo et al. (2017), who suggested that hypocalcemia might be caused by insufficient feed intake before clinical signs of postpartum diseases. Using a matched pair comparison, Jawor et al. (2012) detected greater milk yield $(+6 \mathrm{~kg} / \mathrm{d})$ during wk 2,3 , and, 4 postpartum for cows suffering from subclinical hypocalcemia 0 to 24 $\mathrm{h}$ after calving $(<1.8 \mathrm{mmol} / \mathrm{L})$. These results are supported by another study that found greater milk yield in cows suffering from subclinical hypocalcemia on the first, second, and third DHIA equivalent tests postpartum (Gild et al., 2015). Other studies, however, did not find a difference in milk yield between normocalcemic

Table 4. Cox regression model with shared frailty effects for herds predicting culling within 60 DIM $(\mathrm{n}=$ $1,426)^{1}$

\begin{tabular}{|c|c|c|c|c|c|}
\hline \multirow[b]{2}{*}{ Variable } & \multirow[b]{2}{*}{$\mathrm{HR}^{2}$} & \multirow[b]{2}{*}{ SE } & \multicolumn{2}{|c|}{$95 \% \mathrm{CI}$} & \multirow[b]{2}{*}{$P$-value } \\
\hline & & & Lower CI & Upper CI & \\
\hline \multicolumn{6}{|c|}{ Serum calcium concentration ${ }^{3}$} \\
\hline$\geq 2.0 \mathrm{mmol} / \mathrm{L}$ & Referent & & & & \\
\hline$<2.0 \mathrm{mmol} / \mathrm{L}$ & 1.69 & 0.33 & 1.15 & 2.49 & 0.007 \\
\hline \multicolumn{6}{|l|}{ Twin birth } \\
\hline No & Referent & & & & \\
\hline Yes & 3.84 & 1.71 & 1.60 & 9.21 & 0.003 \\
\hline
\end{tabular}


and hypocalcemic animals irrespective of parity (Martinez et al., 2012; Rodríguez et al., 2017).

Except for the study by Neves et al. (2018), none of the aforementioned studies took previous-lactation milk yield into account. By ignoring previous-lactation milk yield, the association between hypocalcemia and milk yield might be biased. It has been shown that cows with high milk yield in the previous lactation will produce more milk in the subsequent lactation (Nordlund, 2006). However, high milk yield in the previous lactation is also an important risk factor for hypocalcemia (Fleischer et al., 2001).

Post hoc power analyses revealed that the sample size in our study was insufficient to prove a significant effect in primiparous (power $=0.1487$; difference in milk yield $=1.5 \mathrm{~kg} / \mathrm{d} ; \mathrm{SD}=6.0 \mathrm{~kg} / \mathrm{d})$ and multiparous (power $=0.4033$; difference in milk yield $=0.8 \mathrm{~kg} / \mathrm{d}$; $\mathrm{SD}=8.3 \mathrm{~kg} / \mathrm{d}$ ) cows, respectively.

Furthermore, our study demonstrated that multiparous cows with clinical hypocalcemia produced 2.19 $\mathrm{kg} / \mathrm{d}$ less milk during the first 3 mo of lactation. Two previous studies (Rajala-Schultz et al., 1999; Fleischer et al., 2001) based on 20,983 Finnish Ayrshire and 1,074 Holstein Friesian cows, respectively, failed to demonstrate an association of clinical hypocalcemia with milk yield when compared with normocalcemic cows. Data from these studies originate from cows 2 decades ago, and the latter study reported an average 305-d milk yield of $7,802 \mathrm{~kg}$. We speculate that today's dairy cows suffering from clinical hypocalcemia were not able to compensate for the loss of milk caused by recumbency in early lactation. In contrast to the subclinical form, clinical hypocalcemia is a more severe state of maladaptation, therefore affecting milk yield negatively. In a former study it was shown that incidence of clinical hypocalcemia averaged $7.2 \%$ on German dairy farms (Venjakob et al., 2017). Other studies might have had difficulties detecting effects of clinical hypocalcemia, as the incidence of clinical hypocalcemia was low in the studied herds. Moreover, the results on milk production and reproductive performance might be biased by cows with severe cases of clinical hypocalcemia that were euthanized or culled before effects became apparent.

Cows with a serum calcium concentration $<1.9$ $\mathrm{mmol} / \mathrm{L}$ had decreased odds $(\mathrm{OR}=0.56 ; P=0.001)$ of becoming pregnant at first AI. Post hoc power analyses revealed that the sample size in our study was sufficient to prove a significant effect of hypocalcemia on FSCR (power $=0.9863 ;$ difference in $\mathrm{FSCR}=13.0 \% ; \mathrm{n}=$ $1,108)$. Our results suggest that clinical hypocalcemia had no additional negative effect on FSCR compared with a serum calcium concentration $<1.9 \mathrm{mmol} / \mathrm{L}$ only. The threshold of $<1.9 \mathrm{mmol} / \mathrm{L}$ chosen to categorize cows as hypocalcemic was stringent and led to enrollment of more severe cases of hypocalcemia. This might explain why there was no additional negative effect of clinical hypocalcemia.

In a recent study, Caixeta et al. (2017) investigated the association of hypocalcemia with estrus cyclicity and FSCR. The authors took blood samples on the first 3 DIM, and cows with a serum calcium concentration $>2.15 \mathrm{mmol} / \mathrm{L}$ were considered normocalcemic. Subclinical hypocalcemia was defined as serum calcium concentration $\leq 2.15 \mathrm{mmol} / \mathrm{L}$ on 1 of the first 3 DIM, and chronic subclinical hypocalcemia was defined as serum calcium concentration $\leq 2.15 \mathrm{mmol} / \mathrm{L}$ for all 3 DIM measured. Return to cyclicity took longer for cows with persistent subclinical hypocalcemia compared with normocalcemic animals and animals with subclinical hypocalcemia. Moreover, cows with persistent subclinical hypocalcemia had decreased odds of becoming pregnant at first AI.

These observations are confirmed by our data, which also showed that cows with a serum calcium concentration $<1.8 \mathrm{mmol} / \mathrm{L}$ had a significantly reduced hazard of getting pregnant within 150 DIM. On average, it took $25 \mathrm{~d}$ longer for these cows to get pregnant compared with cows with a serum calcium concentration $\geq 1.8 \mathrm{mmol} / \mathrm{L}$. This is in agreement with Martinez et al. (2012), who found a tendency for normocalcemic animals to have a greater risk of pregnancy in 230 DIM compared with hypocalcemic cows. Cows suffering from a clinical or subclinical disease (e.g., subclinical hypocalcemia) were described to have a reduced probability of being cyclic, which might be an explanation for reduced pregnancy among hypocalcemic cows (Ribeiro et al., 2013). These results are strengthened by another recent study that described normocalcemic animals to be estrus cyclic sooner than hypocalcemic cows (Rodríguez et al., 2017). In comparison, Chamberlin et al. (2013) did not find a difference in resumption of cyclicity by 50 to 60 DIM between normocalcemic and hypocalcemic cows.

Cows with a serum calcium concentration $<2.0$ $\mathrm{mmol} / \mathrm{L}$ had a 1.69 greater hazard of being culled during the first 60 DIM. Other authors have reported similar results about the association of hypocalcemia with early-lactation culling. These studies, however, considered longer risk periods for cows to be hypocalcemic. Seifi et al. (2011) found 2.4 times and 5.3 times greater odds for cows being culled when serum calcium concentration was $\leq 2.2 \mathrm{mmol} / \mathrm{L}$ in wk 1 and $\leq 2.3 \mathrm{mmol} / \mathrm{L}$ in wk 2 postpartum, respectively. Further evidence was provided by Roberts et al. (2012), who described that serum calcium concentrations $\leq 2.2$ and $\leq 2.3 \mathrm{mmol} / \mathrm{L}$ in wk 1 and 2 after calving, respectively, were associ- 
ated with an increased culling risk. In contrast, Neves et al. (2018) found that a tendency for greater calcium concentrations in multiparous cows was associated with an increased culling risk in early lactation. Differences between the studied risk period may explain why the results are contradictory. Seifi et al. (2011) and Roberts et al. (2012) considered serum calcium concentration in the first 2 wk postpartum, whereas Neves et al. (2018) analyzed blood samples taken within $12 \mathrm{~h}$ after parturition.

Recently, multiple epidemiological studies have been conducted analyzing the effect of periparturient hypocalcemia on subsequent health and performance (Chapinal et al., 2012a; Chamberlin et al., 2013; Rodríguez et al., 2017; Neves et al., 2018). However, it is difficult to compare our results with these studies because definitions of hypocalcemia, sampling time, and outcomes differ. Although it was not the scope of this study, we tried to consider time from calving to sampling and the interaction of calcium status and sampling time. It seems likely that cows suffering from hypocalcemia for a longer period of time do have a greater risk for negative health and production outcomes. Due to our sampling scheme of 1 sample per cow within $48 \mathrm{~h}$ after calving, we were not able to describe calcium dynamics postpartum. Future studies should implement repeated sampling to elucidate the occurrence of hypocalcemia and effects on outcomes considering time and duration.

Due to the inclusion criteria for herd size (i.e., at least 100 cows), results of our study are not representative of the whole German dairy industry. As bigger farms are primarily found in the northeast of Germany, most of the participating farms were located in this region. Furthermore, farms were not enrolled randomly. Practitioners were invited to participate by an information leaflet. Those responsible for farms with a high prevalence of hypocalcemia might have been more likely to participate in this study. Considering milk yield of breeds, our results should be interpreted with caution because only 1 of the participating dairy farms kept Jersey cows as the predominant breed. It cannot be precluded that our results on reproductive performance were somewhat influenced by the underlying management strategy (e.g., heat detection or timed AI).

\section{CONCLUSIONS}

Including 1,426 cows from 107 farms, our study shows that hypocalcemia within $48 \mathrm{~h}$ after calving was negatively associated with reproduction and culling risk. Cows with a serum calcium concentration $<1.9$ $\mathrm{mmol} / \mathrm{L}$ had decreased odds of becoming pregnant at first AI. The hazard of becoming pregnant within 150 DIM was reduced when cows had a serum calcium con- centration $<1.8 \mathrm{mmol} / \mathrm{L}$. Serum calcium concentration $<2.0 \mathrm{mmol} / \mathrm{L}$ was associated with a 1.69 times greater risk of being culled within the first 60 DIM. The effect on milk yield was conditional on parity. There was no effect on milk yield in primiparous cows with a serum calcium concentration $<2.0 \mathrm{mmol} / \mathrm{L}$, whereas multiparous cows had a tendency to produce more milk when their serum calcium concentration was $<2.1 \mathrm{mmol} / \mathrm{L}$. Presence of clinical hypocalcemia had a negative effect on milk yield. Given the high prevalence of hypocalcemia and the associated undesirable consequences, this study re-emphasizes the need to establish control strategies for hypocalcemia.

\section{REFERENCES}

Ali, A. K. A., and G. E. Shook. 1980. An optimum transformation of somatic cell concentration in milk. J. Dairy Sci. 63:487-490.

Caixeta, L. S., P. A. Ospina, M. B. Capel, and D. V. Nydam. 2017. Association between subclinical hypocalcemia in the first 3 days of lactation and reproductive performance of dairy cows. Theriogenology 94:1-7.

Chamberlin, W. G., J. R. Middleton, J. N. Spain, G. C. Johnson, M. R. Ellersieck, and P. Pithua. 2013. Subclinical hypocalcemia, plasma biochemical parameters, lipid metabolism, postpartum disease, and fertility in postparturient dairy cows. J. Dairy Sci. 96:7001-7013.

Chapinal, N., M. Carson, T. F. Duffield, M. Capel, S. Godden, M. Overton, J. E. Santos, and S. J. LeBlanc. 2011. The association of serum metabolites with clinical disease during the transition period. J. Dairy Sci. 94:4897-4903.

Chapinal, N., M. E. Carson, S. J. LeBlanc, K. E. Leslie, S. Godden, M. Capel, J. E. Santos, M. W. Overton, and T. F. Duffield. 2012a The association of serum metabolites in the transition period with milk production and early-lactation reproductive performance. J. Dairy Sci. 95:1301-1309

Chapinal, N., S. J. Leblanc, M. E. Carson, K. E. Leslie, S. Godden, M. Capel, J. E. Santos, M. W. Overton, and T. F. Duffield. 2012 b. Herd-level association of serum metabolites in the transition period with disease, milk production, and early lactation reproductive performance. J. Dairy Sci. 95:5676-5682.

DeGaris, P. J., and I. J. Lean. 2008. Milk fever in dairy cows: A review of pathophysiology and control principles. Vet. J. 176:58-69.

Dohoo, P. J., S. W. Martin, and H. Stryhn. 2009. Veterinary Epidemiologic Research. 2nd ed. University of Prince Edward Island, Charlottetown, PEI, Canada.

Fleischer, P., M. Metzner, M. Beyerbach, M. Hoedemaker, and W Klee. 2001. The relationship between milk yield and the incidence of some diseases in dairy cows. J. Dairy Sci. 84:2025-2035.

Gild, C., N. Alpert, and M. van Straten. 2015. The influence of SCH on milk production and reproduction in Israeli dairy herds. Isr. J. Vet. Med. 70:16-21.

Goff, J. P. 2008. The monitoring, prevention, and treatment of milk fever and subclinical hypocalcemia in dairy cows. Vet. J. 176:50-57.

Goff, J. P. 2014. Calcium and magnesium disorders. Vet. Clin. North Am. Food Anim. Pract. 30:359-381.

Jawor, P. E., J. M. Huzzey, S. J. LeBlanc, and M. A. von Keyserlingk. 2012. Associations of subclinical hypocalcemia at calving with milk yield, and feeding, drinking, and standing behaviors around parturition in Holstein cows. J. Dairy Sci. 95:1240-1248.

Martín-Tereso, J., and H. Martens. 2014. Calcium and magnesium physiology and nutrition in relation to the prevention of milk fever and tetany (dietary management of macrominerals in preventing disease). Vet. Clin. North Am. Food Anim. Pract. 30:643-670.

Martinez, N., C. A. Risco, F. S. Lima, R. S. Bisinotto, L. F. Greco, E. S. Ribeiro, F. Maunsell, K. Galvao, and J. E. Santos. 2012. Evalu- 
ation of peripartal calcium status, energetic profile, and neutrophil function in dairy cows at low or high risk of developing uterine disease. J. Dairy Sci. 95:7158-7172.

Martinez, N., L. D. Sinedino, R. S. Bisinotto, E. S. Ribeiro, G. C. Gomes, F. S. Lima, L. F. Greco, C. A. Risco, K. N. Galvao, D. Taylor-Rodriguez, J. P. Driver, W. W. Thatcher, and J. E. Santos. 2014. Effect of induced subclinical hypocalcemia on physiological responses and neutrophil function in dairy cows. J. Dairy Sci. $97: 874-887$.

Megahed, A. A., M. W. H. Hiew, S. A. El Badawy, and P. D. Constable. 2018. Plasma calcium concentrations are decreased at least 9 hours before parturition in multiparous Holstein-Friesian cattle in a herd fed an acidogenic diet during late gestation. J. Dairy Sci. 101:1365-1378.

Neves, R. C., B. M. Leno, M. D. Curler, M. J. Thomas, T. R. Overton, and J. A. A. McArt. 2018. Association of immediate postpartum plasma calcium concentration with early-lactation clinical diseases, culling, reproduction, and milk production in Holstein cows. J. Dairy Sci. 101:547-555.

Nordlund, K. V. 2006. Transition cow index. Pages 139-143 in 39th Proc. Am. Assoc. Bovine Practitioners, St. Paul, MN. Frontier, Stillwater, OK.

Oetzel, G. R., and B. E. Miller. 2012. Effect of oral calcium bolus supplementation on early-lactation health and milk yield in commercial dairy herds. J. Dairy Sci. 95:7051-7065.

Pinedo, P., J. Velez, G. Solano, N. Rodriguez, J. Naves, G. M. Schuenemann, and C. Risco. 2017. Effect of oral calcium administration on the cure and reproductive performance of Holstein cows diagnosed with puerperal metritis. J. Dairy Sci. 100:2917-2927.
Rajala-Schultz, P. J., Y. T. Grohn, and C. E. McCulloch. 1999. Effects of milk fever, ketosis, and lameness on milk yield in dairy cows. J. Dairy Sci. 82:288-294.

Reinhardt, T. A., J. D. Lippolis, B. J. McCluskey, J. P. Goff, and R. L. Horst. 2011. Prevalence of subclinical hypocalcemia in dairy herds. Vet. J. 188:122-124.

Ribeiro, E. S., F. S. Lima, L. F. Greco, R. S. Bisinotto, A. P. Monteiro, M. Favoreto, H. Ayres, R. S. Marsola, N. Martinez, W. W. Thatcher, and J. E. Santos. 2013. Prevalence of periparturient diseases and effects on fertility of seasonally calving grazing dairy cows supplemented with concentrates. J. Dairy Sci. 96:5682-5697.

Roberts, T., N. Chapinal, S. J. Leblanc, D. F. Kelton, J. Dubuc, and T. F. Duffield. 2012. Metabolic parameters in transition cows as indicators for early-lactation culling risk. J. Dairy Sci. 95:30573063.

Rodríguez, E. M., A. Aris, and A. Bach. 2017. Associations between subclinical hypocalcemia and postparturient diseases in dairy cows. J. Dairy Sci. 100:7427-7434.

Seifi, H. A., S. J. Leblanc, K. E. Leslie, and T. F. Duffield. 2011. Metabolic predictors of post-partum disease and culling risk in dairy cattle. Vet. J. 188:216-220.

Venjakob, P. L., S. Borchardt, and W. Heuwieser. 2017. Hypocalcemia-Cow-level prevalence and preventive strategies in German dairy herds. J. Dairy Sci. 100:9258-9266.

Wilhelm, A. L., M. G. Maquivar, S. Bas, T. A. Brick, W. P. Weiss, H. Bothe, J. S. Velez, and G. M. Schuenemann. 2017. Effect of serum calcium status at calving on survival, health, and performance of postpartum Holstein cows and calves under certified organic management. J. Dairy Sci. 100:3059-3067. 